\title{
Growth responses on major replacement of animal protein with plant protein and graded levels of dietary supplement amino sugar, glucosamine in threatened Magur (Clarias batrachus, Linnaeus, 1758) fry
}

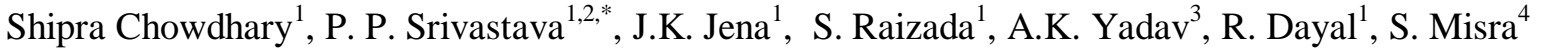 \\ ${ }^{1}$ ICAR-National Bureau of Fish Genetic Resources, Canal Ring Road, Teli Bagh, Lucknow-226 002, India. ${ }^{2}$ Fish Nutrition, Biochemistry and Physiology \\ Division, ICAR-Central Institute of Fisheries Education, Panch Marg, Off Yari Road, Versova, Mumbai - 400061 , MS, India. ${ }^{3}$ Aquaculture Research and \\ Training Unit, ICAR-National Bureau of Fish Genetic Resources, Chinhat, Faizabad Raod, Lucknow-227 105, India. ${ }^{4}$ Babasaheb Bhimrao Ambedkar \\ University, Rae Bareilly Road, Lucknow-226 025, UP, India.
}

\begin{tabular}{l}
\hline ARTICLE INFO \\
\hline Article history: \\
Received on: $29 / 11 / 2015$ \\
Revised on: $17 / 02 / 2016$ \\
Accepted on: $06 / 05 / 2016$ \\
Available online: $26 / 08 / 2016$ \\
\hline
\end{tabular}

Key words:

Glucosamine, Growth, Animal \& Plant protein, Clarias batrachus, Fry.

\begin{abstract}
A 12-week feeding trial was performed to evaluate the use of animal and plant protein, in combination with dietary supplement glucosamine $(\mathrm{GlcN})$ an amino sugar and a prominent precursor in the biochemical synthesis of glycosylated proteins and lipids on threatened Asian catfish fry, Clarias batrachus fry (av. wt. $0.23 \pm 0.02$ to $0.25 \pm 0.03 \mathrm{~g}$ ). Six practical feeds (CP 34.27 to $43.52 \%$, kcal/ $100 \mathrm{~g} 377.1$ to 399 , and total fat 1.67 to $6.70 \%$ ) were formulated on the basis of whole animal or animal-plant combined protein feeds blended with GlcN at 0.5, 5.0 and $10.0 \%$. The six-feeds were prepared by blending with GlcN (F-1, PAG::0:100:0.5; F-2, PAG::0:100:5.0; F-3, PAG::0:100:10.0; F-4, PAG::75:25:0.5; F-5, PAG::75:25:5.0; F-6, PAG::75:25:10.0). The best growth performance was recorded in fish fed F-2 feed among the animal protein group feeding regime (F-1 to F-3) as $0.56 \pm 0.04 \mathrm{~g}$ followed by F-3 $(0.46 \pm 0.02 \mathrm{~g})$ and F-1 $(0.38 \pm 0.02 \mathrm{~g})$. The survival ranged with $60 \pm 4.3$ to $70 \pm 2.4 \%$ in animal protein rich diets whereas, the survival range recorded as $50 \pm 2.4$ to $53 \pm 2.4 \%$ in plant protein rich diets $\mathrm{F}$ 4, F-5 and F-6 in comparison to control feed(F-7) showing $43 \pm 1.4 \%$ survival. The survival significantly $(\mathrm{p}<0.05)$ improved in GlcN supplemented feeds $(50 \pm 2.4$ to $70 \pm 2.4 \%)$ in comparison to control $(43 \pm 1.4 \%)$. The synergistic growth on supplementing proteins and GlcN showed significant variation $(\mathrm{p}<0.05)$ in case of weight gain, FCR, SGR and PER. Results suggests that animal protein feeds were much acceptable than plant protein diets by $C$. batrachus fry and the dietary supplement amino sugar GlcN showed a significant role in survival and growth of the fish at early stage of life.
\end{abstract}

\section{INTRODUCTION}

Feedstuffs of animal origins are in general considered alternative protein sources because their protein context is higher and their supplements of indispensable amino acids is better to those of plant origin [1]. Fishmeal has been substituted by one type of animal protein sources such as maggot meal [2], black soldier fly pupae meal [3], poultry by-product meal [4], poultry viscera meal [5], and feather meal [6]. The major part of the world's animal food protein comes from the fish; hence it is essential to secure fish health in rearing systems [61, 62, 63].

* Corresponding Author

Email : ppsicar@gmail.com, Fax+91-22 26361573;

Ph: +91-22-26361446
The successful fish culture requires use of efficient feed with optimum composition and output. When fish are raised in closed systems or in high density ponds, they must be provided with a better diet, complete and nutrient balanced, allowing rapid fish growth and good health. Thus, the complete fish feed is essential to provide all essential nutritional components like carbohydrates, lipids, proteins, vitamins and minerals [64, 65]. Substantial research efforts have been made in the recent past towards replacement of fish meal by sustainable alternative plant ingredients sources. The suitability of this nutrient replacement, in terms of survival, and growth performance is highly variable among fish species and rearing conditions. Available knowledge shows that a sensible blending of different plant proteins is needed to balance the indispensable amino acid 
profile in order to minimize the requirement of amino acid supplementation in a balanced diet [49, 50,51,52]. It has been experimented that dietary incorporation of soymeal, groundnut cake and winged bean improved the growth performance, feed intake and feed efficiency of Clarias gariepinus [53,54,55,56,57]. The level and balance of amino acids found in soy protein are considered to be the most appropriate plant proteins, although low in methionine level [58,59]. Soybean meal is currently the very commonly used plant source protein source in fish feeds and comprises up to $50 \%$ of the aquaculture diet[60] though other sources of cheaper plant protein sources such as cottonseed meal, sunflower meal, linseed, rapeseed meal, sorghum, corn meal, mustard, sesame, copra, leguminous seeds and leucaena have been advocated in view of reducing feed cost $[6,7,8,9,10,11,49]$. Up to $80 \%$ of fishmeal protein was replaced by a combination of processed blood meal and meat meal (4:1) with no bad effect on growth, survival, or efficiency in Epinephelus coioides [12]. In general, higher substitutions of plant source protein as a complete replacement for fishmeal protein have resulted in poor growth and feed efficiency in fish particularly those requiring animal protein as a must $[13,14,15,16,17,18]$ reported that incorporation of plant protein by replacing fishmeal did not have a significant effect on the whole body composition of Indian major carps, L. rohita, C. catla and C. mrigala. Similarly, Pongmaneerat \& Watanabe[19] reported that soybean meal as the sole protein source did not greatly influence the body protein content of carps. Hence, the dietary requirement of protein is different in various fish species $[20,21,22,23,24]$ reported that partial replacement of FM protein with SBM protein in tilapia diet did not compromise growth of the fish. Substitution of various soy products have shown better growth in many fishes including catfishes [8,25,26,27]. Recently, Sarowar et al. [28] have studied the impacts of different diets on survival and growth in C. batrachus grow-outs. C. batrachus, a native to Asia, is one of the most popular fish of aquaculture and aquarium trade among the Asian species [29, 92]. Clarias batrachus, belonging to family Clariidae. It is now called Clarias magur, is an air-breathing threatened [30], endangered [31] catfish. It is a promising aquaculture candidate species owing to its

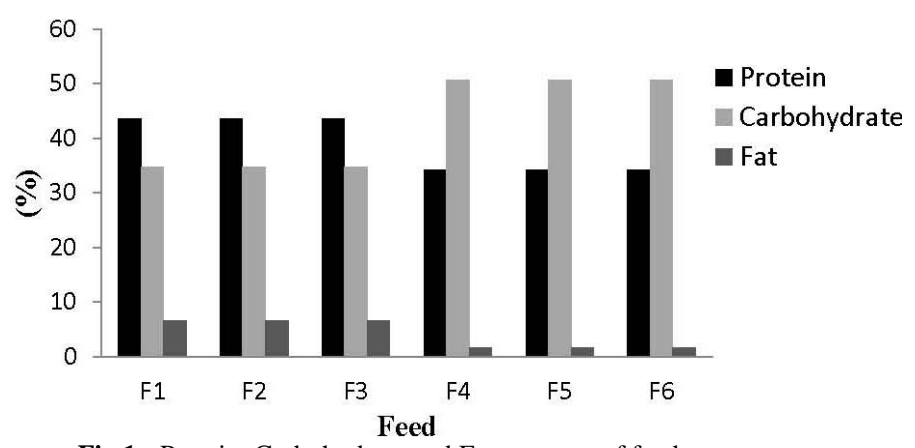

Fig.1: Protein, Carbohydrate and Fat contents of feeds. good flavour, medicinal importance, growth, hardiness, efficient food conversion efficiency, excellent nutritional profile and high market values $[32,33,34]$. The objective of the present study was to evaluate and assess the effect of major replacement of animal protein with soybean meal in diet formulations of $C$. batrachus fry in captive rearing conditions with the support blending of glucosaimine $(\mathrm{GlcN})$. The assessment criteria included for the study were the key nutritional parameters such as growth, survival, feed utilization and carcass composition.

\section{MATERIALS AND METHODS}

\subsection{Experimental feeds and preparation}

Six feeds were prepared by using plant $\&$ animal protein in combination with GlcN source for Asian catfish, Clarias batrachus. The feed ingredients and proximate composition of the experimental feeds are given in Table - 1. The natural live feed serves as control. In the experiment, six (34.27 to $43.52 \%$ crude protein, 377.1 to $399 \mathrm{kcal} / 100 \mathrm{~g}$, and crude lipid 1.67 to $6.70 \%$ ) practical feeds were formulated and their composition is given in Table - 2, Fig. $1 \& 2$. The animal and plant protein component of the feeds was progressively added with GlcN 0.0, 0.5, 5.0 and $10.0 \%$ with basic ingredients like silkworm pupae, fish meal, casein and soybean meal (F-1, PAG::0:100:0.5; F-2, PAG::0:100:5.0; F-3, PAG::0:100:10.0; F-4, PAG::75:25:0.5; F5, PAG::75:25:5.0; F-6, PAG::75:25:10.0). Fishmeal was freshly prepared from in lab from dried trash fishes mainly Puntius sophore, Mystus vittatus, etc. Live silkworm pupae were procured from Department of Applied Animal Science, Babasaheb Bhimrao Ambedkar University, Raebareilly Road, Lucknow, cultured upto $\mathrm{VI}^{\text {th }}$ Instar larvae \& then de-oiled in the lab by di-ethyl-ether (Merck). The de-oiled pupae was dried in oven at $60{ }^{\circ} \mathrm{C}$ for an hour and powdered and used for feed preparation. The feeds were prepared by mixing of the dry ingredients in a mixer and water was added to make hard dough. Each feed was pressure cooked for 15 minutes for the proper gelatinization of the ingredients. Finally the pressure cooked moist feeds were stored in plastic bags in a deep freezer $\left(-20^{\circ} \mathrm{C}\right)$ until used.

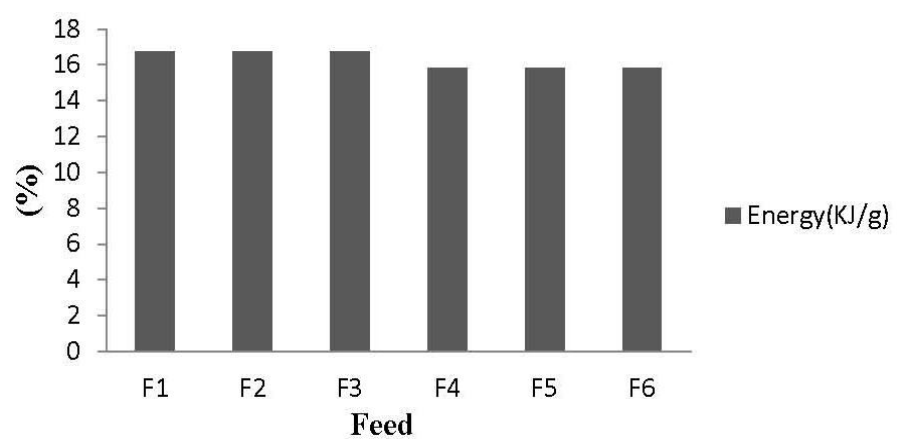

Fig. 2: Gross energy (kJ/g) contents of feeds. 
Table 1: Ingredients composition (w/w) of feeds for Clarias batrachus Fry.

\begin{tabular}{|c|c|c|c|c|c|c|c|}
\hline Ingredients & $\begin{array}{c}\text { F1 } \\
\text { PAG 0:100:0.5 }\end{array}$ & $\begin{array}{c}\text { F2 } \\
\text { PAG 0:100:5.0 }\end{array}$ & $\begin{array}{c}\text { F3 } \\
\text { PAG 0:100:10.0 }\end{array}$ & $\begin{array}{c}\text { F4 } \\
\text { PAG 75:25:0.5 }\end{array}$ & $\begin{array}{c}\text { F5 } \\
\text { PAG 75:25:5.0 }\end{array}$ & $\begin{array}{c}\text { F6 } \\
\text { PAG 75:25:10.0 }\end{array}$ & $\begin{array}{l}\text { Control } \\
\text { NATFO } \\
\end{array}$ \\
\hline Soybean meal $^{1}$ & 0.0 & 0.0 & 0.0 & 45.6 & 45.6 & 45.6 & - \\
\hline Silkworm Pupae & 20.3 & 20.3 & 20.3 & 5.06 & 5.06 & 5.06 & - \\
\hline Fish Meal & 20.3 & 20.3 & 20.3 & 5.07 & 5.07 & 5.07 & - \\
\hline Casein $^{2}$ & 20.2 & 20.2 & 20.2 & 5.07 & 5.07 & 5.07 & - \\
\hline $\mathrm{GlcN}(\text { Chitosamine }-\mathrm{HCl})^{3}$ & 0.5 & 5.0 & 10.0 & 0.5 & 5.0 & 10.0 & - \\
\hline $\mathrm{Starch}^{4}$ & 32.0 & 27.5 & 22.5 & 32.0 & 27.5 & 22.5 & - \\
\hline $\mathrm{CMC}^{5}$ & 2.2 & 2.2 & 2.2 & 2.2 & 2.2 & 2.2 & - \\
\hline Papain $^{6}$ & 2.0 & 2.0 & 2.0 & 2.0 & 2.0 & 2.0 & - \\
\hline $\mathrm{VM}+\mathrm{MM}^{7}$ & 2.5 & 2.5 & 2.5 & 2.5 & 2.5 & 2.5 & - \\
\hline Natural -Live food & - & - & - & - & - & & 100.0 \\
\hline Total & 100 & 100 & 100 & 100 & 100 & 100 & 100 \\
\hline \multicolumn{8}{|c|}{ 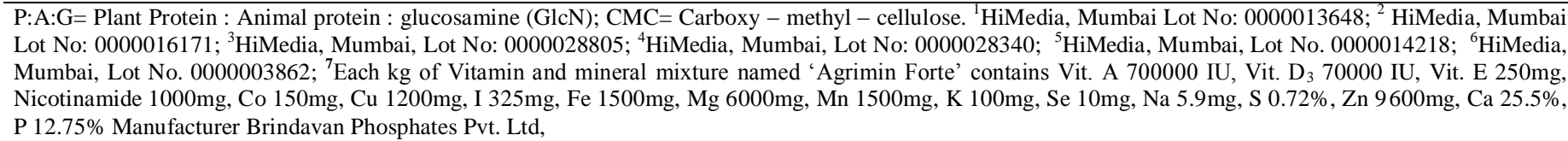 } \\
\hline
\end{tabular}

Table 2: Calculated values of Protein, carbohydrate, fat and energy composition of feeds

\begin{tabular}{|c|c|c|c|c|c|c|}
\hline & F1 & F2 & F3 & F4 & F5 & F6 \\
\hline Total Protein & 43.52 & 43.52 & 43.52 & 34.27 & 34.27 & 34.27 \\
\hline Carbohydrate & 34.70 & 34.70 & 34.70 & 50.66 & 50.66 & 50.66 \\
\hline Total Fat & 6.70 & 6.70 & 6.70 & 1.67 & 1.67 & 1.67 \\
\hline GE/ kg (K.Cal) & 3990.48 & 3990.48 & 3990.48 & 3771.5 & 3771.5 & 3771.5 \\
\hline KJ.g $\mathbf{g}^{-1}$ & 16.76 & 16.76 & 16.76 & 15.84 & 15.84 & 15.84 \\
\hline
\end{tabular}

\subsection{Fish and Feeding Trial}

Newly hatched larvae of catfish, Clarias batrachus took from a one batch of hatchery bred spawned brooders were used in the experiment after acclimatization for 7 days. In the wet laboratory, the experimental fish, C. batrachus fry (av. wt. $0.23 \pm$ 0.02 to $0.25 \pm 0.03 \mathrm{~g}$ ) were subsequently segregated and stocked in separate specially designed plastic pool (cap. 300 l, containing $50 \mathrm{l}$ of bore water with 24 hour aeration), in a groups of 100 fry in every pool. The experiment consisted of two replications for each feed and continued for 84 days. Each scheduled daily ration per batch of fish was divided into two equal proportions and distributed to the fish at 11:00 hr and 17:00 hr. Initial and subsequent fortnight weight gains (g) were observed and recorded on electronic balance (make: Sartorius). At the end of the experimentation, 6-8 fishes from each treatment were sacrificed and analyzed for proximate composition of the muscles. The water quality parameters were recorded for water temp, $\mathrm{pH}$, dissolved oxygen and total alkalinity.

\subsection{Analytical methods \& Statistical analyses of data}

Proximate compositions of feeds and fish carcasses were analyzed following AOAC methods[35] 1990. All samples were analysed in triplicate. Dry matter was estimated after drying in oven at $105^{\circ} \mathrm{C}$ for 24 hours; crude protein $(\mathrm{N} \times 6.25)$ by the Kjeldahl method after acid digestion; Crude lipid by di-ethyl ether extraction method using Soxhlet apparatus. The growth performance of the feeds, in terms of the weight gain (\%), Specific growth rate (SGR), feed conversion ratio (FCR), Protein efficiency ratio (PER) were calculated using the following equations. The growth in length and weight and the survival data were analysed using two-way ANOVA. Duncan's multiple Range test was used to determine which treatment mean differed significantly $(\mathrm{P}<0.05)$ using SPSS version 16.0.

Weight Gain $(\%)=\{($ Final body weight $)-($ Initial body weight $) /$ (Initial body weight) $\} \times 100$

Specific Growth Rate $($ SGR; \%day- 1$)=\{($ Final body weight $)-($ Initial body weight)/(experimental days) $\} \times 100$

Survival $(\%)=100 \times$ (No. of total fish - No. of dead fish)/Number of total fish

Biomass $=$ Final average weight $\mathrm{x}$ Total no. of fish

Feed Conversion ratio $(\mathrm{FCR})=$ Feed given $($ dry weight $) /$ Body weight gain (wet weight).

\section{RESULTS}

Various water quality parameters: water temperature, $\mathrm{pH}$ and dissolved oxygen (DO), total alkalinity were observed and found to be least affected by different feeds. The values of all the parameters of water, i.e. temperature, $\mathrm{pH}$, alkalinity and $\mathrm{DO}$ were almost similar for all the feeding treatments during the experimental period and were well within the range. The water quality recorded for water temp, dissolved oxygen, $\mathrm{pH}$ and alkalinity as $20-24{ }^{\circ} \mathrm{C}, 6.8-7.5,6.9-7.4 \mathrm{ppm}$ and $130-138$ ppm, respectively (APHA[95].

The survival and average fish weight gain shown graphically in Table- 3 \& Table- 4 and Fig. $3 \& 4$ respectively. The best growth was recorded in fish fed $\mathrm{F} 2$ among the animal protein group feeding regime (F1 to F3) as $0.56 \pm 0.04 \mathrm{~g}$ followed by F3 $0.46 \pm 0.02 \mathrm{~g}$ and $\mathrm{F} 10.38 \pm 0.02 \mathrm{~g}$. The survival range $60 \pm 4.3$ to $70 \pm 2.4 \%$. The survival range recorded as $50 \pm 2.4$ to $53 \pm 2.4 \%$ in 
F4, F5 and F6. The control feed showing $43+1.4 \%$ survival. The growth of the fry was recorded better in animal protein fed fishes but there is no sign of dose-dependent changes on growth performances.

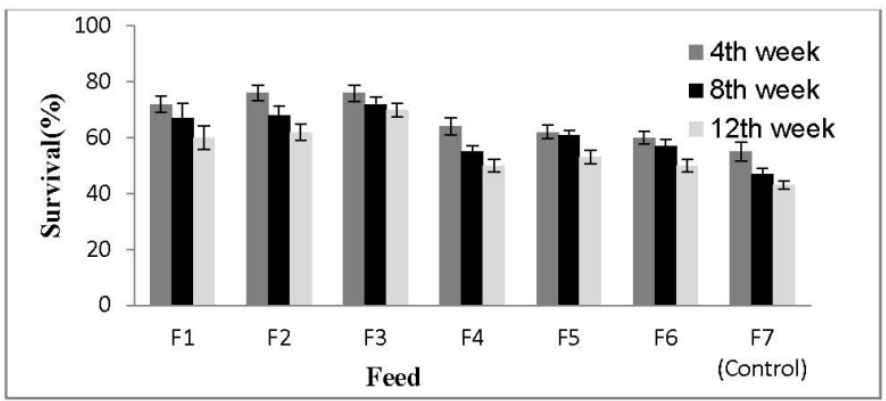

Fig. 3: Survival percentage of fishes till 12th week.

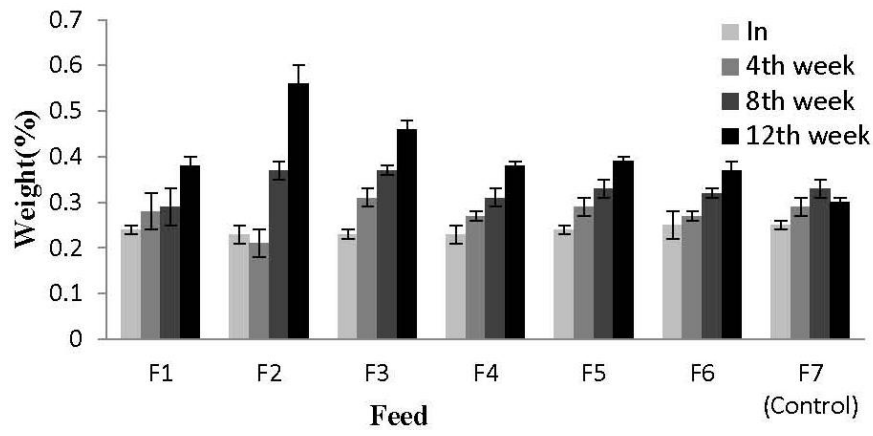

Fig. 4: Weight gain percentage of fishes till 12th week.

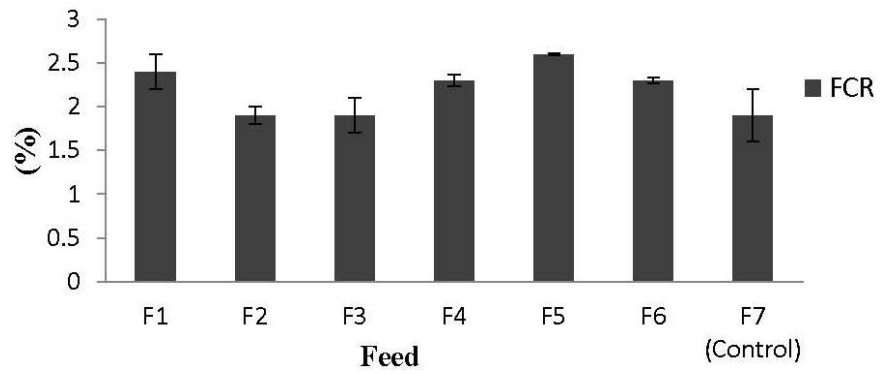

Fig. 5: Feed Conversion Ratio (FCR).

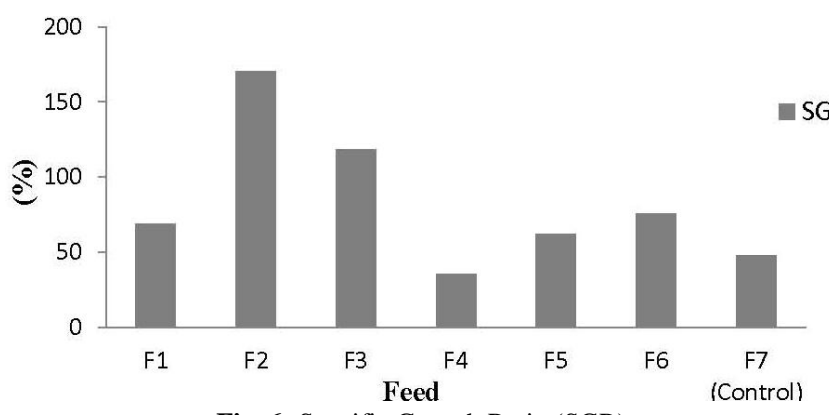

Fig. 6: Specific Growth Ratio (SGR).

The best growth recorded in F2 which contains 5.0\% GlcN with $100 \%$ animal protein. The plant protein rich diets exhibited poor growth performance in comparison to animal protein rich diets. The control recorded poor growth after 84 day experimental period. The results of FCR, SGR, PER, Feed intake and Protein intake are shown in Table-5, and FCR, SGR, PER in Fig. 5, 6 and 7. The proximate composition is depicted in Table -6 , Fig. 08 \& 09.

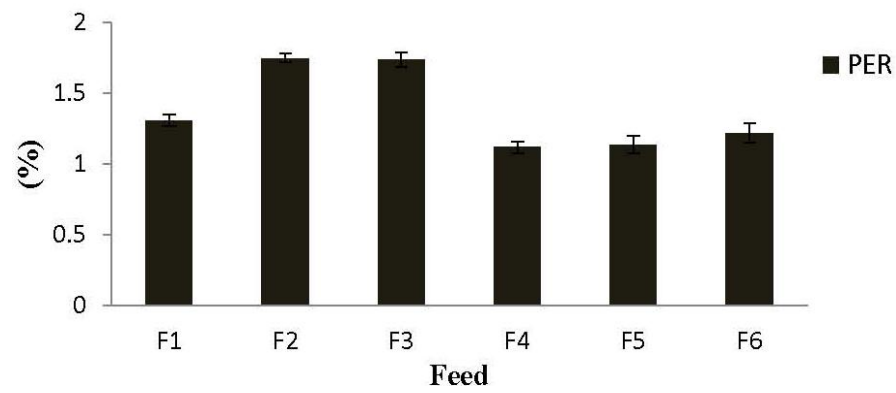

Fig. 7: Protein Efficiency Ratio (PER).

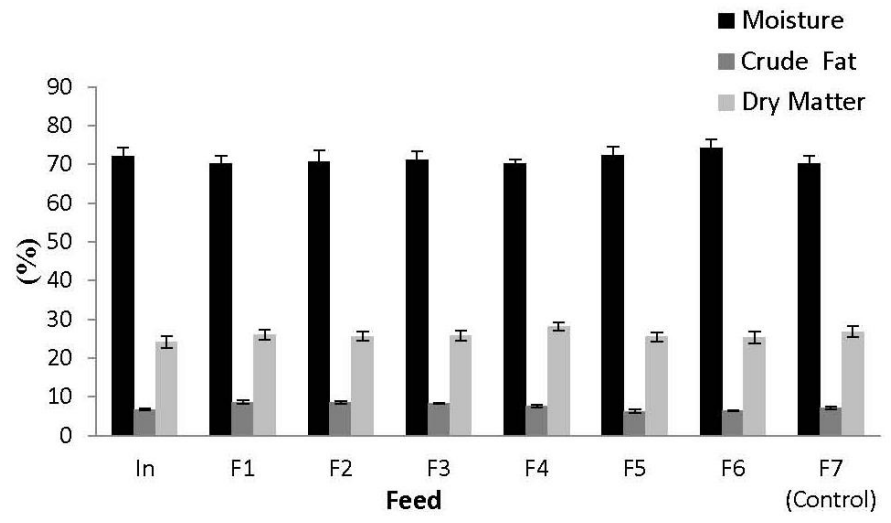

Fig. 8: Moisture, Crude Fat and Dry matter of fish carcass.

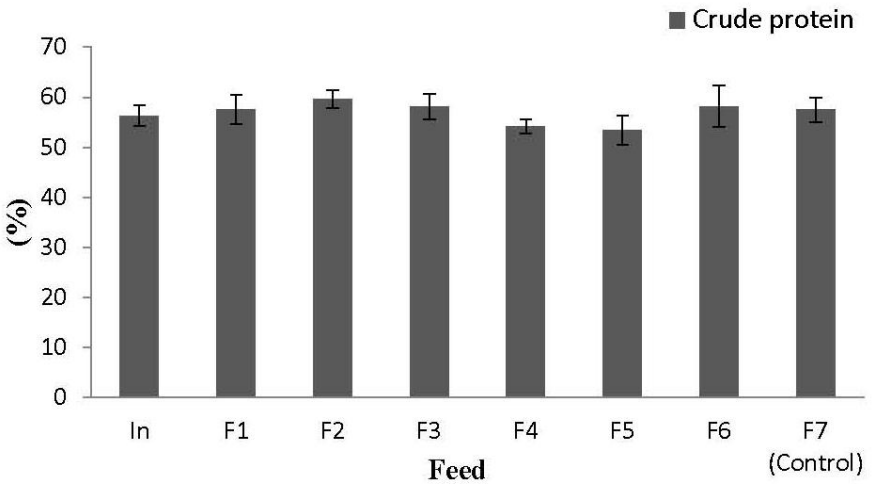

Fig. 9: Crude protein of fish carcass after 12th week.

The synergistic growth on supplementing protein and GlcN showed significant variation $(\mathrm{p}<0.05)$ in case of weight gain, FCR, SGR, PER, however there is no change $(p>0.05)$ in feed intake and protein intake in all the treatments. 
Table 3: Survival Percentage of Clarias batrachus fry reared for 12 weeks.

\begin{tabular}{|c|c|c|c|c|}
\hline Feed & Stocking Nos. ( $\mathrm{N}=100 \mathrm{X} 2$ replicates $)$ & $4^{\text {th }}$ Week & $8^{\text {th }}$ Week & $12^{\text {th }}$ Week \\
\hline F-1 & 200 & $72 \pm 2.8^{\mathrm{a}}$ & $67 \pm 5.2^{\mathrm{a}}$ & $60 \pm 4.3^{\mathrm{b}}$ \\
\hline F-2 & 200 & $76 \pm 2.7^{\mathrm{a}}$ & $68 \pm 3.2^{\mathrm{b}}$ & $62 \pm 2.9^{c}$ \\
\hline F-3 & 200 & $76 \pm 2.9^{\mathrm{a}}$ & $72 \pm 2.7^{\mathrm{b}}$ & $70 \pm 2.4^{\mathrm{b}}$ \\
\hline F-4 & 200 & $64 \pm 3.0^{\mathrm{a}}$ & $55 \pm 2.2^{\mathrm{b}}$ & $50 \pm 2.4^{\mathrm{b}}$ \\
\hline F-5 & 200 & $62 \pm 2.4^{\mathrm{a}}$ & $61 \pm 1.5^{\mathrm{b}}$ & $53 \pm 2.4^{\mathrm{b}}$ \\
\hline F-6 & 200 & $60 \pm 2.4^{\mathrm{a}}$ & $57 \pm 2.3^{\mathrm{b}}$ & $50^{ \pm} 2.4^{\mathrm{c}}$ \\
\hline F-7 (control) & 200 & $55 \pm 3.3^{\mathrm{a}}$ & $47^{ \pm} 2.1^{\mathrm{b}}$ & $43 \pm 1.4^{\mathrm{b}}$ \\
\hline
\end{tabular}

Same alphabet in superscript in a column represents no significant difference in weight gain, $*=p<0.05$. The results are of duplicate sets of feeding trial. Values $= \pm$ SE

Table 4: Growth of Clarias batrachus fry reared for 12 weeks.

\begin{tabular}{|c|c|c|c|c|}
\hline Feeds & In & $4^{\text {th }}$ week & $8^{\text {th }}$ week & $12^{\text {th }}$ week \\
\hline F1 & $0.24 \pm 0.01^{\mathrm{a}}$ & $0.28 \pm 0.04^{\mathrm{a}}$ & $0.29 \pm 0.04^{\mathrm{a}}$ & $0.38 \pm 0.02^{\mathrm{c}}$ \\
\hline F2 & $0.23 \pm 0.02^{\mathrm{a}}$ & $0.21 \pm 0.03^{b}$ & $0.37 \pm 0.02^{b}$ & $0.56 \pm 0.04^{\mathrm{c}}$ \\
\hline F3 & $0.23 \pm 0.01^{\mathrm{a}}$ & $0.31 \pm 0.02^{\mathrm{a}}$ & $0.37 \pm 0.01^{b}$ & $0.46 \pm 0.02^{\mathrm{d}}$ \\
\hline F4 & $0.23 \pm 0.02^{\mathrm{a}}$ & $0.27 \pm 0.01^{\mathrm{a}}$ & $0.31 \pm 0.02^{\mathrm{a}}$ & $0.38 \pm 0.01^{\mathrm{c}}$ \\
\hline F5 & $0.24 \pm 0.01^{\mathrm{a}}$ & $0.29 \pm 0.02^{\mathrm{a}}$ & $0.33 \pm 0.02^{b}$ & $0.39 \pm 0.01^{\mathrm{c}}$ \\
\hline F6 & $0.25 \pm 0.03^{\mathrm{a}}$ & $0.27 \pm 0.01^{\mathrm{a}}$ & $0.32 \pm 0.01^{\mathrm{c}}$ & $0.37 \pm 0.02^{\mathrm{d}}$ \\
\hline F7 (control) & $0.25 \pm 0.01^{\mathrm{a}}$ & $0.29 \pm 0.02^{\mathrm{a}}$ & $0.33 \pm 0.02^{\mathrm{c}}$ & $0.30 \pm 0.01^{\mathrm{b}}$ \\
\hline
\end{tabular}

Same alphabet in superscript in a column represents no significant difference in weight gain. $*=p<0.05$. The results are of duplicate sets $(\mathrm{n}=2)$ of feeding trial.

Values $=$ mean $\pm \mathrm{SE}$

Table 5: Growth performance, nutrient utilization in Clarias batrachus fry reared for 12 weeks.

\begin{tabular}{|c|c|c|c|c|c|c|c|c|c|c|c|}
\hline 远 & 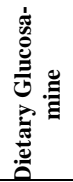 & 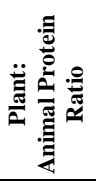 & $\begin{array}{l}\text { BD } \\
\Xi \\
\Xi \\
\Xi\end{array}$ & 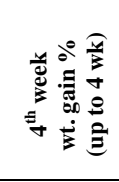 & 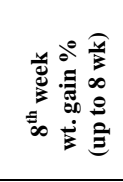 & 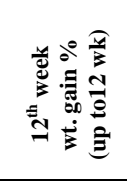 & 茿 & $\begin{array}{l}\stackrel{0}{0} \\
\frac{0}{0}\end{array}$ & $\begin{array}{l}\stackrel{2}{2} \\
\frac{1}{c}\end{array}$ & 葛 & 总总 总 \\
\hline F1 & 0.5 & $100: 0$ & $0.24 \pm 0.01^{\mathrm{a}}$ & $16.6 \pm 1.2^{\mathrm{a}}$ & $20.8 \pm 1.3^{\mathrm{a}}$ & $58.3 \pm 4.7^{\mathrm{a}}$ & $2.4 \pm 0.2^{\mathrm{a}}$ & 69.11 & $1.31 \pm 0.04^{\mathrm{a}}$ & $342 \pm 20^{\mathrm{a}}$ & $106.0 \pm 4^{\mathrm{a}}$ \\
\hline $\mathrm{F} 2$ & 5.0 & 100:0 & $0.23 \pm 0.02^{\mathrm{a}}$ & $8.7 \pm 0.9^{\mathrm{b}}$ & $60.8 \pm 4.5^{\mathrm{b}}$ & $143.5 \pm 8.3^{b}$ & $1.9 \pm 0.1^{\mathrm{b}}$ & 170.5 & $1.75 \pm 0.03^{\mathrm{b}}$ & $600 \pm 31^{\mathrm{b}}$ & $187.6 \pm 11^{\mathrm{b}}$ \\
\hline F3 & 10.0 & 100:0 & $0.23 \pm 0.01^{\mathrm{a}}$ & $34.78 \pm 3.1^{\mathrm{c}}$ & $60.6 \pm 3.1^{\mathrm{b}}$ & $100.1 \pm 7.6^{\mathrm{c}}$ & $1.9 \pm 0.2^{\mathrm{b}}$ & 118.8 & $1.74 \pm 0.05^{\mathrm{b}}$ & $420 \pm 18^{c}$ & $130.9 \pm 8^{\mathrm{c}}$ \\
\hline F4 & 0.5 & $75: 25$ & $0.23 \pm 0.02^{\mathrm{a}}$ & $17.4 \pm 0.04^{\mathrm{a}}$ & $34.8 \pm 0.07^{\mathrm{c}}$ & $65.2 \pm 0.02^{\mathrm{a}}$ & $2.3 \pm 0.07^{\mathrm{a}}$ & 35.29 & $1.12 \pm 0.04^{\mathrm{c}}$ & $132 \pm 11^{\mathrm{d}}$ & $72.1 \pm 4^{\mathrm{d}}$ \\
\hline F5 & 5.0 & $75: 25$ & $0.24 \pm 0.01^{\mathrm{a}}$ & $20.8 \pm 0.03^{\mathrm{a}}$ & $37.5 \pm 0.04^{\mathrm{c}}$ & $62.5 \pm 0.03^{\mathrm{a}}$ & $2.6 \pm 0.1^{\mathrm{a}}$ & 62.34 & $1.14 \pm 0.06^{\mathrm{c}}$ & $218 \pm 19^{e}$ & $83.0 \pm 4^{\mathrm{e}}$ \\
\hline F6 & 10.0 & $75: 25$ & $0.25 \pm 0.03^{\mathrm{a}}$ & $8.0 \pm 0.01^{\mathrm{d}}$ & $28.0 \pm 0.05^{\mathrm{d}}$ & $48.0 \pm 0.02^{\mathrm{d}}$ & $2.3 \pm 0.3^{\mathrm{a}}$ & 75.52 & $1.22 \pm 0.07^{\mathrm{a}, \mathrm{c}}$ & $237 \pm 14^{\mathrm{e}}$ & $101.0 \pm 9^{\mathrm{a}}$ \\
\hline F7 & - & - & $0.25 \pm 0.01^{\mathrm{a}}$ & $16.0 \pm 0.02^{\mathrm{a}}$ & $32.0 \pm 0.03^{\mathrm{c}}$ & $20.0 \pm 0.03^{\mathrm{e}}$ & $1.9 \pm 0.3^{\mathrm{b}}$ & 48.04 & - & $136 \pm 15^{\mathrm{d}}$ & - \\
\hline & 0.5 & - & $0.23 \pm 0.02^{\mathrm{a}}$ & $17.4 \pm 1.2^{\mathrm{a}}$ & $27.4 \pm 1.3^{\mathrm{d}}$ & \multirow{3}{*}{$60.5 \pm 4.2^{\mathrm{a}}$} & $2.3 \pm 0.4^{\mathrm{a}, \mathrm{b}}$ & 51.75 & $1.20 \pm 0.02^{\mathrm{c}}$ & $236 \pm 18^{\mathrm{e}}$ & $88.3 \pm 4^{\mathrm{e}}$ \\
\hline & 5.0 & - & $0.24 \pm 0.01^{\mathrm{a}}$ & $6.2 \pm 0.3^{\mathrm{d}}$ & $48.3 \pm 2.8^{\mathrm{e}}$ & & $2.2 \pm 0.8^{\mathrm{a}}$ & 120.19 & $1.42 \pm 0.08^{\mathrm{d}}$ & $423 \pm 17^{\mathrm{c}}$ & $141.3 \pm 4^{\mathrm{c}}$ \\
\hline & 10.0 & - & $0.24 \pm 0.02^{\mathrm{a}}$ & $22.3 \pm 2.4^{\mathrm{a}}$ & $52.2 \pm 1.6^{\mathrm{e}}$ & & $2.2 \pm 0.2^{\mathrm{a}}$ & 92.42 & $1.54 \pm 0.10^{\mathrm{d}}$ & $327 \pm 12^{\mathrm{a}}$ & $120.7 \pm 4^{\mathrm{a}, \mathrm{c}}$ \\
\hline $\begin{array}{l}\text { Animal Protein } \\
100 \%\end{array}$ & - & $0: 100$ & $0.24 \pm 0.03^{\mathrm{a}}$ & $17.2 \pm 1.3^{\mathrm{a}}$ & $43.2 \pm 3.4^{\mathrm{c}}$ & $98.1 \pm 4.9^{\mathrm{c}}$ & $2.2 \pm 0.1^{\mathrm{a}}$ & 121.17 & $1.22 \pm 0.12^{\mathrm{a}, \mathrm{c}}$ & $422 \pm 24^{c}$ & $134.8 \pm 10^{\mathrm{c}}$ \\
\hline Plant protein & - & $75: 25$ & $0.24 \pm .04^{\mathrm{a}}$ & $15.2 \pm 0.5^{\mathrm{a}}$ & $33.8 \pm 1.3^{\mathrm{c}}$ & $55.2 \pm 1.7^{\mathrm{a}}$ & $2.4 \pm 0.7^{\mathrm{a}}$ & 60.27 & $1.15 \pm 0.01^{\mathrm{c}}$ & $189 \pm 15^{f}$ & $81.3 \pm 4.7^{\mathrm{e}}$ \\
\hline
\end{tabular}

Mean Values in same column with different superscript letters are significantly different $(\mathrm{P}<0.05)$.

Values are mean $\pm \mathrm{SE}$ of duplicate determinations $(\mathrm{n}=2)$. In $=$ Initial weight of fish before feeding.

SGR $=$ Specific Growth Ratio; FCR $=$ Feed Conversion Ratio ;PER = Protein Efficiency Ratio

$\mathrm{FI}=$ Feed Intake; PI = Protein Intake

Table 6: Whole body proximate composition ( $\left.\mathrm{g} \cdot \mathrm{kg}^{-1} \mathrm{DM}\right)$ of Clarias batrachus fry fed feeds containing different proteins for $12^{\text {th }}$ week.

\begin{tabular}{|c|c|c|c|c|c|c|c|c|}
\hline Parameters $\left(\right.$ g.kg $\left.{ }^{-1}\right)$ & In $W_{t}$ & F1 & F2 & F3 & F4 & F5 & F6 & F7 (Control) \\
\hline Moisture & $72.2 \pm 2.1^{\mathrm{a}}$ & $70.3 \pm 2.0^{\mathrm{b}}$ & $70.8 \pm 2.8^{\mathrm{b}}$ & $71.2 \pm 2.2^{\mathrm{a}, \mathrm{b}}$ & $70.3 \pm 1.1^{\mathrm{b}}$ & $72.5 \pm 2.1^{\mathrm{a}}$ & $74.3 \pm 2.2^{\mathrm{c}}$ & $70.3 \pm 1.9^{b}$ \\
\hline Crude Fat & $6.8 \pm 0.3^{\mathrm{a}}$ & $8.7 \pm 0.4^{\mathrm{b}}$ & $8.5 \pm 0.3^{b}$ & $8.3 \pm 0.2^{\mathrm{b}}$ & $7.6 \pm 0.3^{\mathrm{c}}$ & $6.3 \pm 0.5^{\mathrm{a}}$ & $6.4 \pm 0.2^{\mathrm{a}}$ & $7.2 \pm 0.3^{\mathrm{c}}$ \\
\hline Crude Protein & $56.3 \pm 2.1^{\mathrm{a}}$ & $57.6 \pm 2.9^{\mathrm{a}}$ & $59.7 \pm 1.8^{\mathrm{b}}$ & $58.1 \pm 2.6^{\mathrm{b}}$ & $54.2 \pm 1.4^{\mathrm{c}}$ & $53.4 \pm 2.9^{\mathrm{c}}$ & $58.2 \pm 4.1^{\mathrm{b}}$ & $57.5 \pm 2.4^{\mathrm{a}}$ \\
\hline Dry Matter & $24.2 \pm 1.5^{\mathrm{a}}$ & $26.1 \pm 1.3^{\mathrm{b}}$ & $25.6 \pm 1.2^{\mathrm{b}}$ & $25.8 \pm 1.2^{\mathrm{b}}$ & $28.2 \pm 1.0^{\mathrm{c}}$ & $25.5 \pm 1.2^{\mathrm{b}}$ & $25.3 \pm 1.5^{\mathrm{b}}$ & $26.9 \pm 1.4^{\mathrm{b}}$ \\
\hline
\end{tabular}

Mean Values in same row with different sunerscrint letters are significantlv different $(\mathrm{P}<0.05)$.

\section{DISCUSSION}

Yuan and co-workers [36] concluded that fermented Soybean meal is an acceptable alternative plant protein source that can replace up to $35 \%$ of fish meal protein in diets in juvenile Chinese sucker, Myxocyprinus asiaticus without significant adverse effects on survival, growth, PER FCR, and body composition. Dietary proteins play a dominant role in fish growth
[37, 38, 39, 40, 41, 42]. Whether fish will better accept plant or animal protein or combination of both will rest on the type of food habits of the species. In general, herbivorous fishes have a capacity to digest and assimilate plant protein better than the omnivorous or carnivorous fishes whereas, omnivore or carnivore fishes perform better with animal protein.

$\mathrm{Yu}$ and co-workers [94] indicated that replacement level up to $40 \%$ did not affect the growth, FCR, PER and body 
composition of juvenile Chinese sucker. However, several of the studies have concluded that even herbivorous fishes when fed with sizable part of animal protein perform better in terms of growth and general health. Rohu, a herbivore fish, when fed separately with plant protein and a combination of plant and animal protein at $35 \%$ protein level performed better growth when fed a mixture of both plant and animal protein [43]. Davis \& Stickney [44] reported no difference in weight increment of blue tilapia fed diets containing FM or FM-free diets with 74\% SBM. Soybean meal is a world- widely available, cheaper protein source with relatively higher digestible protein and energy contents and good amino acid profile[45]. Soybean products as dietary protein source has been reported to affect the growth and feed utilization of many fish species including channel catfish [46,47], tilapia [24,48], rainbow trout $[49,66,68,69]$, red drum [67,70], seabream [71], Asian catfish [27], cobia [72] and cuneate drum [73]. Amongst the animal proteins, fish meal, meat-meal, goat liver, fish and poultry offal's used as fish diet in case of catfishes particularly in C. batrachus, fish meal has always been considered to perform better in terms of survival, growth and general well-being [74,75,76,77]. The reason being, fish meal has superior nutritive values over other animal [93] and plant proteins [78], because of its well-balanced amino acid composition and bioavailability [79], which influenced overall growth performance of animal [80]. However, when fish meal is incorporated partly with other animal proteins like goat liver and shrimp-meal, no significant difference was observed in the final body weight, per cent weight gain and net biomass in $C$. batrachus [76]. Similar results were also obtained in the present case as fish fed with mixed animal proteins performed better than the control (F7) and also with feed F4, F5 \& F6 prepared by mixing 50\% share of both plant and mixed animal proteins. This makes clear that the use of fish meal may be partly supplemented with other animal protein feeds without affecting overall dietary nutritional requirements of Clarias batrachus. The dietary protein levels influences the growth, feed efficiency, fish tissue proximate composition, and that the inclusion of dietary protein in the range of $40-43 \%$ of the diet is optimum for the growth and efficient feed utilization of protein in Heteropneustes fossilis. [49, 69, 81, 82, 83,84]. C. batrachus belonging to the same family (siluridae), having similar food and feeding habits performed better when fed protein levels of around 40\% [76] and hence the share of protein of 37.39 to $43.52 \%$ in the present diets could be considered ideal for this species. Replacement of 75-100\% fishmeal finally resulted in down trend growth and feed utilization and also decreased survival percentage. However, the economic viability is a point to be considered as the survival was higher in animal origin protein fed animals (approx. 60 to $70 \%$ ) than in plant protein fed animals (approx. 50 to 53\%). Poor growth of fish has been shown on to the presence of chitinous material in maggot meal and keratin protein in feather meal, which may be more difficult for fish to digest[85]. $5 \%$ GlcN in feed with animal protein gave better survival and growth than 0.5 or $10.0 \% \mathrm{GlcN}$ in the present study, which shows that $5.0 \%$ level of GlcN along with animal protein is good for the health of this fish. However, this was found different in case of plant protein, which showed better performance at $10 \% \mathrm{GlcN}$. A good piece of work on the effects of GlcN in case of marine shrimps has been documented but not on fishes. Dietary GlcN has been reported as a growth promoting factor in marine shrimps [86, 87]. The beneficial effects of dietary chitin on the growth and survival of juvenile Penaeus monodon has also been documented $[88,89]$. In what way, the GlcN helps in improving survival and growth in shrimps has not been well understood and, therefore, needs to be reviewed in future studies. Prawn shell waste protein is rich in essential amino acids [90,91] and hence GlcN which is derived from the prawn shell may have some of the essential amino acids which may be prompting higher growth in fish in the instant study. The GlcN has also been shown to reduce free radicals, tissue breakdown, articular cartilage cell death and inflammation in animals and is commonly used as a diet supplement particularly for the treatment of osteoarthritis in human being. It is an amino sugar produced in nature by the body from glucose and glutamine (an amino acid). $\mathrm{GlcN}$ is needed to produce glycosamineo-glycans, as they are major compositions of cartilaginous tissues.

\section{CONCLUSION}

Our results indicate that an animal protein rich feed when blended with GlcN are more acceptable and has direct impact on survival and growth promotion than natural feeds in $C$. batrachus. GlcN being derived from crustacean exoskeleton might also provide natural food flavour to this fish as crustacean's forms major share of diet in $C$. batrachus in natural feeding. The potential of replacing major quantities of animal protein with soybean meal in the feeds of fish needs more evaluation along with synergistic effects/approach of incorporating glucosamine $(\mathrm{GlcN})$ in future research studies.

\section{ACKNOWLEDGEMENTS}

Director, National Bureau of Fish Genetic Resources (NBFGR), Lucknow has provided the necessary facilities and materials required during the study and deeply acknowledged for the same.

\section{REFERENCES}

1. Robinson EH, Li MH. Comparison of practical diets with and without animal protein at various concentrations of dietary protein for performance of channel catfish Ictalurus punctatus raised in earthen ponds. J World Aquaculture Society. 1998; 29: 273-280.

2. Adewolu MA. The use of maggot meal as a protein source in the diet of Clarias gariepinus fingerlings. Res. Comm. Fish. 2001; 1(1): 1120.

3. St-Hilaire S, Sheppard C, Tomberlin JK, Irving S, Newton L, McGuire MA, Mosley E, Hardy RW, Sealey W. Fly pre-pupae as a feedstuff for rainbow trout Oncorhynchus mykiss. J World Aquaculture Society. 2007; 38(1): 59-67.

4. Turker A, Yigit M, Ergun S, Karaali B, Erteken A. Potential of poultry by-product meal as a substitute for fishmeal in diets for Black Sea turbot Scophthalmus maeoticus: Growth and nutrient utilization in winter. Israel Journal of Aquaculture - Bamidgeh. 2005; 57(1) : 49-61. 
5. Usman R, Palingi NN, Ahmad T. Utilization of local feed ingredients in tiger grouper grow out moist diets. Aquacult Asia Mag. 2007; AprilJune : 33-36.

6. Hasan MR, Haq MS, Das PM, Mowlah G. Evaluation of poultryfeather meal as a dietary protein source for Indian major carp Labeo rohita fry. Aquaculture. 1997; 151: 47-54.

7. Garg SK, Kalla A, Bhatnagar A. Evaluation of raw and hydrothermically processed leguminous seeds as supplementary feed for the growth of two Indian major carp species. Aquaculture Research. 2002; 33: 151-163.

8. El-Saidy DMSD, Gaber MMA. Replacement of fish meal with a mixture of different plant protein sources in juvenile Nile tilapia, Oreochromis niloticus (L ) diets. Aquaculture Research. 2003; 34: 1119-1127.

9. Heikkinen J, Vielma J, Kemiläinen O, Tiirola M, Eskelinen P, Kiuru T, Navia-Paldanius D, Von Wright A. Effects of soybean meal based diet on growth performance gut histopathology and intestinal microbiota of juvenile rainbow trout (Oncorhynchus mykiss). Aquaculture. 2006; 261: 259-268.

10. Abbas S, Ahmed I, Salim M, Rehman K. Comparative effects of fertilization and supplementary feed on growth performance of three fish species International. Journal of Agricultural Biology. 2010; 12: 276-280.

11. Jahan DA, Hussain L, Islam MA, Khan MM, Nima A. Use of soybean as partial substitute of fish meal in the diets of Rohu Labeo rohita (Ham ) fry. The Agriculturists. 2012; 10(2): 68-76.

12. Millamena OM. Replacement of fishmeal by animal by-product meals in a practical diet for grow-out culture of grouper Epinephelus coioides. Aquaculture. 2002; $204: 75-84$.

13. Ballestrazzi R, Lanari D, D'Agaro E, Mion A. The effect of dietary protein level and source on growth body composition total ammonia and reactive phosphate excretion of growing sea bass (Dicentrarchus labrax). Aquaculture. 1994; 127 : 197-206.

14. Boonyaratpalin M, Suraneiranat P, Tunpibal T. Replacement of fishmeal with various types of soybean products in diets for the Asian seabass Lates calcarifer. Aquaculture. 1998; 161: 67- 78.

15. Francis G, Makkar HPS, Becker K. Anti-nutritional factors present in plant-derived alternate fish feed ingredients and their effects in fish. Aquaculture. 2001; 199: 197-227.

16. Dersjant-Li Y. The use of soy protein in aquafeeds In: Cruz-Sua'rez L E Ricque-Marie D Tapia-Salazar M Gaxiola-Corte's M G Simoes N(eds)Avances en Nutricio'n Acur'cola VI Memorias del VI Simposium Internacional de Nutricio'n Acui'cola 3 al 6 de Septiembre del 2002 Cancu'n Quintana Roo Me'xico. 2002; pp 541-558.

17. Bilgüven $M$, Barış $M$. Effects of the feed containing different plant protein sources on growth performance and body composition of rainbow trout (Oncorhynchus mykiss). Turkish Journal of Fisheries and Aquatic Sciences. 2011; 11: 345-350.

18. Khan N, Ashraf M, Qureshi NA, Sarker PK, Vandenberg GW, Rasool F. Effect of similar feeding regime on growth and body composition of Indian major carps (Catla catla Cirrhinus mrigala and Labeo rohita) under mono and polyculture. African Journal of Biotechnology. 2012; 11(44): 10280-10290.

19. Pongmaneerat J, Watanabe T. Nutritional evaluation of soybean meal for rainbow trout and carp. Nippon Suisan Gakkai. 1993; 59(1): 157163.

20. Anderson RJ, Kienbolz EW, Flickinger SA. Protein requirements of small mouth bass and largemouth bass. Journal of Nutrition. 1981; $111: 1085-1097$

21. Kim KW, Wang XJ, Bai SC. Optimum dietary protein level for maximum growth of juvenile olive flounder Paralichthys olivaceus. Aquaculture Research. 2002; 33: 673-679.

22. Nose T, Arai S. Optimum level of protein in purified diet in eel Anguilla japonica Bull Freshwater Fish Res Lab. 1972; 22: 145-55.

23. Ogino C, Saito K. Protein in fish-J The utilization of dietary protein by young carp. Bull Jpn Soc Set Fish. 1970; 36: 250-254

24. Shiau S, Lin S, Yu S, Lin A, Kwok C. Defatted and full-fat soybean meal as partial replacements for fishmeal in tilapia
(Oreochromis niloticus $\mathrm{X} \mathrm{O}$ aureus) diets at low protein level. Aquaculture. 1990; $86: 401-407$.

25. Ustaoğlu S, Rennert B. The apparent nutrient digestibility of diets containing fish meal or isolated soy protein in starlet (Acipenser ruthenus). International Review of Hydrobiology. 2002; 87: 577-584.

26. Eid AE, Elfattah BA, Mohamed K. Effect of fishmeal substitution by plant protein sources on growth performance and body composition of gilthead sea bream (Sparus aurata) fingerlings. J Arabian Aquaculture Society. 2008; 3: 58-79.

27. Chowdhary S, Srivastava PP, Misra S, Dayal R, Yadav AK, Jena JK. Evaluation of partial replacement of dietary animal protein from plant protein blended with GlcN on growth and body indices of Asian Catfish (Clarias batrachus) fingerlings. Journal of Aquaculture Research Development. 2012; 3: 129.

28. Sarowar MN, Jewel MZH, Sayeed MA, Mollah MFA. Impacts of different diets on growth and survival of Clarias batrachus Growouts. International Journal of Biological Research. 2010; $1: 08-12$.

29. Ng HH, Kottelat M. The identity of Clarias batrachus (Linnaeus 1758) with the designation of a neotype (Teleostei: Clariidae). Zoological Journal of the Linnean Society. 2008; 153 : 725-732.

30. Argungu LA, Christianus A, Amin SMN, Daud SK, Siraj SS, Aminur Rahman M. Asian Catfish Clarias batrachus (Linnaeus 1758) Getting Critically Endangered. Asian Journal of Animal and Veterinary Advances. 2013; 8 :168-176 DOI: 10 3923/ajava 2013 168176

31. Vishwanath W. Clarias magur In: IUCN 2013 IUCN Red List of Threatened Species Version 2013. 2010; 1.

32. Hossain Q, Hossain MA, Parween S. Artificial breeding and nursery practices of Clarias batrachus (Linnaeus 1758). Science World. 2006; 4: 32-37.

33. Goswami B. Magur (Clarias batrachus) seed production using low hatcheries. Aquaculture Asia Magazine. 2007; 12:14-16 14.

34. Debnath S. Clarias batrachus the medicinal fish an excellent candidate for aquaculture and employment generation. International Conference Asia Agriculture Animal. IPCBEE IACSIT Press Singapore. 2011: 13 32-47.

35. AOAC (Association of Official Analytical Chemists) In: Helrich K (ed) Official methods of analysis of the Association of Official Analytical Chemists 15th edn Association of Official Analytical Chemists Arlington. 1990; 1298pp.

36. Yuan YC, Lin YC, Yang HJ, Gong Y, Gong SY, Yu DH. Evaluation of fermented soybean meal in the practical diets for juvenile Chinese sucker, Myxocyprinus asiaticus. Aquaculture Nutrition. 2013; 19: 74-83.

37. Cowey CB, Pope JA, Adron JW, Blair A. Studies on the nutrition of marine flatfish; the protein requirements of plaice (Pleuronectes platessa). British Journal of Nutrition. 1972; 28: 447-56.

38. Satia BP. Quantitative protein requirements of rainbow trout. Progressive Fish Culturist. 1974; 36: 80- 85.

39. Cho CY, Slinger SJ, Bayley HS. Influence of level and type of dietary protein and level of feeding on feed utilization by Rainbow trout. Journal of Nutrition. 1976; $106: 1547-155$.

40. Mazid MA, Tanaka T, Katayama KL, Simpson C, Chichester O. Growth response of Tilapia zilli fingerlings fed iso-caloric feeds with variable protein levels. Aquaculture. 1979; 18:115-122.

41. Mundheim H, Aknes A, Hope B. Growth feed efficiency and digestibility in salmon (Salmo salar) fed different dietary proportions of vegetable protein sources in combination with two fish meal qualities. Aquaculture. 2004; 237: 315-331.

42. Mart1'nez-Llorens S, Vidal AT, Garcia IJ, Torres MP, Cerda MJ. Optimum dietary soybean meal level for maximizing growth and nutrient utilization of on-growth gilthead sea bream (Sparus aurata). Aquaculture Nutrition. 2009; 15: 320-328.

43. Rao LM, Kumar S. Effect of squillameal on the growth and nutritive value of Labeo rohita (Ham ). Asian Fisheries Science. 2006; 19: 215-225.

44. Davis AT, Stickney RR. Growth responses of Tilapia aurea to dietary protein quality and quantity. Trans American Fish Society. 1978; 107: 479-483. 
45. Hertrampf JW, Piedad-Pascual F. Handbook on Ingredients for Aquaculture Feeds. Kluwer Academic Publishers Dordrecht. 2000; pp 482-483.

46. Webster CD, Tidwell JH, Goodgame LS, Yancey DH, Mackey L. Use of soybean meal and distillers grains with soluble as partial or total replacement of fish meal in diets for channel catfish Ictalurus punctatus. Aquaculture. 1992; $106: 301-309$.

47. Peres H, Lim C, Klesius PH. Nutritional value of heat-treated soybean meal for channel catfish (Ictalurus punctatus). Aquaculture. 2003; $225: 67-82$.

48. Shiau S, Kwok C, Kwang J, Chen C, Lee S. Replacement of fishmeal with soybean meal in male tilapia (Oreochromis niloticus $\mathrm{X}$ $\mathrm{O}$ aureus) fingerling diets at a sub-optimal protein level. $\mathrm{J}$ World Aquaculture Society. 1989; 20: 230-235.

49. Kaushik SJ, Coves D, Dutto G, Blanc D. Almost total replacement of fish meal by plant protein sources in the diet of a marine teleost the European seabass Dicentrarchus labrax. Aquaculture. 2005; 230: 391-404.

50. Schulz C, Wickert M, Kijora CJ, Ogunji Rennert B. Evaluation of pea protein isolate as alternative protein source in diets for juvenile tilapia Oreochromis niloticus. Aquaculture Research. 2007; 38: 537545.

51. Dias J, Conceição LEC, Ribeiro AR, Borges P, Valente LMP, Dinis MT. Practical diet with low fish-derived protein is able to sustain growth performance in gilthead seabream Sparus aurata during the grow-out phase. Aquaculture. 2009; 293: 255-262.

52. Silva JMG, Espe M, Conceição LEC, Dias J, Valente LMP. Senegalese sole juveniles (Solea senegalensis Kaup 1858) grow equally well on diets devoid of fish meal provided the dietary amino acids are balanced. Aquaculture. 2009; 296: 309-317.

53. Balogun MA, Ologhobo DA. Growth performance and nutrient utilization of fingerling Clarias gariepinus(Burchell) fed raw and cooked soy bean diets. Aquaculture. 1989; 76: 119-126.

54. Degani G, Benzvi Y, Levanon D. The effect of different protein levels and temperature on feed utilization growth and body composition of Clarias gariepinus (Burchell 1922). Aquaculture. 1989; 76: 293-301.

55. Hoffman LC, Prinsloo JF, Rukan G. Partial replacement of fish meal with either soybean meal brewers yeast or tomato meal in the diets of African sharp tooth catfish Clarias gariepinus. Water S A. 1997; 23: 181-186.

56. Fagbenro OA. Apparent digestibility of various oilseed cakes/meals in African catfish diets. Aquaculture International. 1998; 6: 317-322.

57. Fagbenro OA. Comparative evaluation of heat-processed winged bean (Psophocarpus tetragonolobus) meals as partial replacement for fish meal in diets for the African catfish (Clarias gariepinus). Aquaculture. 1999; 170: 297-305.

58. Storebakken T, Refstie S, Ruyter B. Soy products as fat and protein sources in fish feed for intensive aquaculture In: Drackley JK (ed) Soy in animal nutrition Fed. Anim Sci Soc Savoy IL; 2000.

59. Abdel-Warith AA, Younis EM, Al-Asgah Abdualla N. Influence of dietary inclusion of full-fat soybean meal and amino acids supplementation on growth and digestive enzymes activity of Nile tilapia Oreochromis niloticus. Turkish Journal of Fisheries and Aquatic Sciences. 2012; 12: 1-2.

60. NRC. Nutrient requirements of fish National Research Council National Academy Press Washington; 1999.

61. Delong DC Halver JE Mertz ET. Nutrition of salmonid fishes-VI Protein requirements of Chinook salmon at two water temperatures. Journal of Nutrition. 1958; $65: 589-599$.

62. Bhuiyan AK, Begum MA, Hoq ME. Final report on the survey of potential fish feed ingredients of Bangladesh on the basis of their availability and biochemical composition. Fisheries Research Institute Mymensingh. 1989; 70 pp.

63. Tripathi G, Harsh S. Fenvelarate induced macromolecular changes in the catfish Clarias batrachus. Journal of Environmental Biology. $2002 ; 23: 143-146$.
64. Gangadhara B, Nandeesha MC, Varghese JJ, Keshavanath P. Effect of varying protein and lipid levels on the growth of Rohu Labeo rohita. Asian Fisheries Science. 1997; 10:139-147.

65. Cho SH, Lee SM, Lee JH. Effect of dietary protein and lipid levels on growth and body composition of juvenile turbot (Scophthalmus maximus L ) reared under optimum salinity and temperature conditions. Aquaculture Nutrition. 2005; $11: 235-240$.

66. Bureau DP, Harris AM, Cho CY. The effects of purified alcohol extracts from soy products on feed intake and growth of chinook salmon (Oncorhynchus tshawytscha) and rainbow trout (Oncorhynchus mykiss). Aquaculture. 1998; 161: 27-43.

67. Reigh RC, Ellis SC. Effects of dietary soybean and fish-protein ratios on growth and body composition of red drum (Sciaenops ocellatus) fed isonitrogenous diets. Aquaculture. 1992; $104: 279$ 292.

68. Refstie S, Helland SJ, Trond S. Adaptation to soybean meal in diets for rainbow trout Oncorhynchus mykiss. Aquaculture. 1997; $153: 263-272$.

69. Refstie S, Korsoen OJ, Storebakken T, Baeverfjord G, Lein I, Roem AJ. Differing nutritional responses to dietary soybean meal in rainbow trout (Oncorhynchus mykiss) and Atlantic Salmon (Salmo Salar). Aquaculture. 2000; $190: 49-63$.

70. McGoogan BB, Gatlin DM III. Effects of replacing fish meal with soybean meal in diets for red drum Sciaenops ocelltus and potential for palatability enhancement. Journal of World Aquaculture Society. 1997; 28: 374-385.

71. Hernandez MD, Martinez FJ, Jover M, Garcia GB. Effects of partial replacement of fish meal by soybean meal in sharp-snout seabream (Diplodus puntazzo) diet. Aquaculture. 2007; 263: 159167.

72. Chou RL, Her B, Su MS, Hwang G, Wu YH, Chen HY. Substituting fish meal with soybean meal in diets of juvenile cobia Rachycentron canadum. Aquaculture. 2004; 229: 325-333.

73. Wang Y, Kong LJ, Li C, Bureau DP. Effect of replacing fish meal with soybean meal on growth feed utilization and carcass composition of cuneate drum (Nibea miichthioides). Aquaculture. 2006; 261:1307-1313.

74. Giri SS, Sahoo SK, Sahu AK, Mohanty SN, Mukhopadhyay PK. Growth feed utilization and carcass composition of catfish Clarias batrachus (Linn.) fingerlings fed on dried fish and chicken viscera incorporated diets. Aquaculture Research. 2000a; 31 : 767-771.

75. Giri SS, Sahoo SK, Sahu AK, Mohanty SN, Mukhopadhyay PK. Nutrient digestibility and intestinal enzyme activity of Clarias batrachus (Linn ) juveniles fed on dried fish and chicken viscera incorporated diets. Bioresource Technology. 2000b; 71:97-101.

76. Giri SS, Sahoo SK, Lenka S, Rangacharyalu, Paul BN, Sahu AK, Mohanty SN, Mukhopadhyay PK. Effects of partial replacement of dietary fish meal goat liver and shrimp meal on growth and survival of Clarias batrachus. Indian Journal of Animal Science. 2005; 75 (8): 977-981.

77. Khan KS, Ang KJ, Ambak MA. The effect of varying dietary protein level on the growth food conversion protein utilization and body

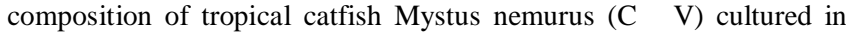
static pond water system. Aquaculture Research. 1996; 27: 823-829.

78. Eyo AA. The utilization of iso-nitrogenous feed mixtures containing blood meal fish meal groundnut cake and soybean meal by fingerling mudfish Clarias anguillaris In: The Annual Report of National Institute of Freshwater Fish Research Nigeria.1991; pp 96-103.

79. Moon HYL Gatlin DM III. Effects of dietary animal proteins on growth and body composition of the red drum (Sciaenops oscellatus). Aquaculture. 1994; 120: 327-340.

80. Gaylord TG, Gatlin DM III. Determination of digestibility coefficients of various feed stuffs for red drum (Sciaenosps ocellatus). Aquaculture. 1996; 139: 303-314.

81. Wee KL, Tacon AGJ. A preliminary study on the dietary protein requirements of Juvenile snakehead. Bulletin of Japanese Society Sci. fish. 1982; 48 (10) : 1463-1468. 
82. Krogdahl $\mathrm{A}^{\circ}$, Bakke-McKellep AM, Baeverfjord G. Effects of graded levels of standard soybean meal on intestinal structure mucosal enzyme activities and pancreatic response in Atlantic salmon (Salmo salar). Aquaculture Nutrition. 2003; 9:361-371.

83. Romarheim OH, Skrede A, Gao Y, Kroogdahl A $\mathrm{A}^{\mathrm{o}}$, Denstadli V, Lilleeng E, Storebakken T. Comparison of white flakes and toasted soybean meal partly replacing fish meal as protein source in extruded feed for rainbow trout (Oncorhynchus mykiss). Aquaculture. 2006; $256: 354-364$.

84. Siddiqui TQ, Khan MA. Effects of dietary protein levels on growth feed utilization protein retention efficiency and body composition of young Heteropneustes fossilis (Bloch). Fish Physiology and Biochemistry. 2009; 35: 479-488.

85. Emre Y, Sevgilis H, Diler I. Replacing fish meal with poultry by-product meal in practical diets for mirror carp (Cyprinus carpio) fingerlings. Turkish Journal of Fisheries and Aquatic Sciences. 2003; $3: 81-85$

86. Kitabayashi K, Kurata H, Shudo K, Nakamura K, Ishikawa S. Studies on formula feed for Kuruma prawn- III On the growth promoting effects of both arginine and methionine. Bulletin Tokai Reg. Fish Res. Lab. 1971; 65 :119-127.

87. Vaitheswaran S, Ahamad AS. Evaluation of certain substances as growth promoting agents for the prawn Penaeus indicus. Indian Journal of Fish.(1986; 33: 95-105.

88. Lan CC, Pan BS. In vitro digestibility simulating the proteolysis of feed protein in the midgut gland of grass shrimp (Penaeus monodon). Aquaculture. 1993; $109: 59-70$.

89. Sudaryono A, Tsvetnenko E, Evans LH. Digestibility studies on fisheries by- product based diets for Penaeus monodon. Aquaculture. 1996; 143(3-4): 331-340.

90. Forster JRM. Studies on the development of compounded diets for prawns In: Proceedings of the first International Conference on Aquaculture Nutrition (Price KS Jr Shaw WN Danberg KS eds ) Delaware Sea Grant College Program US/Japan Aquaculture Panel College of Marine studies University of Delaware Newark NJ USA 1975; pp 229-248.
91. Penaflorida VD. An evaluation of indigenous protein sources as potential component in the feed formulation for the Tiger prawn (Penaeus monodon) using essential amino acid index. Aquaculture. 1989; 83: 319-330.

92. Ng W-K, Soon SC, Hashim R. The dietary protein requirement of a bagrid catfish Mystus nemurus (Cuvier Valenciennes) determined using semi purified diets of varying protein level. Aquaculture Nutrition. 2001: $7: 45-51$.

93. Seenappa D, Devaraj KV. Effect of different levels of protein fat and carbohydrate on growth feed utilization and body carcass composition of fingerlings in Catla catla (Ham.). Aquaculture. 1995; $129: 243-249$.

94. Yu DH, Gong SY, Lin YC. Effects of replacing fishmeal with soyabean meal on growth body composition and digestive enzyme activities of juvenile Chinese sucker Myxocyprinus asiaticus. Aquaculture Nutrition. 2013; $19: 84-90$.

95. APHA. Standard Methods for the examination of water and wastewater $16^{\text {th }}$ edition Published by American Public Health Association Washington DC; 2005.

\section{How to cite this article:}

Chowdhary S, Srivastava PP, Jena JK, Raizada S, Yadav AK, Dayal R, Misra S. Growth responses on major replacement of animal protein with plant protein and graded levels of dietary supplement amino sugar, glucosamine in threatened Magur (Clarias batrachus, Linnaeus, 1758) fry. J App Biol Biotech. 2016; 4 (04): 042-050. DOI: 10.7324/JABB.2016.40404 